\title{
Growth and Fruit Biochemical Characteristics of Three Strawberry Genotypes under Different Potassium Concentrations of Nutrient Solution
}

https://doi.org/10.1515/opag-2018-0039

received May 8, 2018; accepted August 16, 2018

\begin{abstract}
A nutrient solution experiment was performed to evaluate the growth, yield and fruit biochemical characteristics of strawberry under different potassium levels of nutrient solution. Potassium concentrations including 235 (control), 350, 450 and $600 \mathrm{mg} \mathrm{L}^{-1}$ were applied to three strawberry genotypes of Camarosa, Selva and Parus under hydroponic culture. In the three genotypes, the maximum leaf area was observed at $350 \mathrm{mg} \mathrm{L}^{-1} \mathrm{~K}$, and the maximum shoot fresh weight was either at $350 \mathrm{mg} \mathrm{L}^{-1}$ (in Camarosa and Parus) or at $400 \mathrm{mg} \mathrm{L}^{-1}$ (in Selva). In Selva, higher yield was produced by higher $\mathrm{K}$ concentrations than control (17-33\%) and in Camarosa, the maximum yield was produced at $350 \mathrm{mg} \mathrm{L}^{-1}(16 \%)$, whereas fruit yield in Parus was not affected by K concentrations. In Selva and Parus application of $350 \mathrm{mg} \mathrm{L}^{-1}$ potassium produced more fruits than control. The maximum fruit vitamin $\mathrm{C}$ content in Camarosa and Selva was at $350 \mathrm{mg} \mathrm{L}^{-1}$, and in Parus at 450 $\mathrm{mg} \mathrm{L}^{-1}$, while the significant lowest in three genotypes was at $600 \mathrm{mg} \mathrm{L}^{-1}$. Fruit titratable acidity and $\mathrm{pH}$ in Camarosa and Selva, and fruit TSS in Parus were not affected by $\mathrm{K}$ levels. Fruit total soluble solids (TSS) in Camarosa and Selva were maximum in 350 and $450 \mathrm{mg} \mathrm{L}^{-1}$. Increasing K concentrations of nutrient solution increased leaf and fruit $\mathrm{K}$ concentration than control. The results indicate that overall plant growth and fruit quality of three strawberry genotypes were increased by $350 \mathrm{mg} \mathrm{L}^{-1}$ potassium, while application of $600 \mathrm{mg} \mathrm{L}^{-1}$ reduced most traits than control. The Selva genotype had also a better response to higher concentration of $\mathrm{K}$ than two other genotypes.
\end{abstract}

\footnotetext{
*Corresponding author: Mohammad Kazem Souri, Dept. of Horticultural Sciences, Tarbiat Modares Uni., Tehran-Iran,

E-mail:mk.souri@modares.ac.ir

Ghasem Tohidloo, Dept. of Seed Science Technology, Azad Uni. of Karaj, Karaj-Iran

Samaneh Eskandarpour, Dept. of Horticulture, Azad Uni. of Jiroft,
} Jiroft-Iran
Keywords: fertilization, fortification, fruit quality, hydroponic, Camarosa, Parus, plant nutrition, Selva

\section{Introduction}

Adequate supply of mineral nutrients is necessary for optimum growth and acceptable fruit quality in horticultural crops. This goal can be achieved by application of various fertilizers in soil or mineral salts in hydroponic production systems (Fageria et al. 2007; Souri 2016). Among necessary mineral nutrients, potassium (K) is a key nutrient with diverse roles in plant physiology and biochemistry (Marschner, 2011). Potassium may be a limiting factor for crop production especially in high yielding varieties (Hartz et al. 1999; Lin et al. 2004; Ebrahimi et al. 2012; Mardanlu et al. 2014). The use of K-efficient crop genotypes along with the application of K-containing fertilizers may be a viable strategy to improve the yield and reduce the cost of crop production (Fageria et al. 2007).

Potassium is the second most important nutrient, which has direct and indirect roles in many metabolic processes in plant cells including photosynthesis, primary and secondary metabolism, translocation of photo assimilates and their storage (Cerda et al. 2008; Marschner 2011). It has also significant metabolic functions in many quality aspects of products due to higher cell wall stability, regulation of biochemical reactions and different roles in enzymes and antioxidant activities (Demiral and Koseoglu 2005; El-Bassiony 2006; Zivdar et al. 2016). Potassium is the most abundant cation in the cytoplasm and helps to maintain the cell $\mathrm{pH}$ in an optimum range, by which many enzymatic reactions can take place (Human and Kotze 1990; Marschner 2011). Its various companion anions have important role in osmotic adjustment and water relation of plant tissues (Lin et al. 2004; Zivdar et al. 2016). In addition, enhanced potassium content in food 
products can guarantee their superior quality that can also promote human health conditions.

In many fruiting crops such as strawberry, tomato and maize, the demand for $\mathrm{K}$ uptake is relatively high during fruit development. The general Hoagland nutrient solution concentration of $\mathrm{K}$ is $235 \mathrm{mg} \mathrm{L}^{-1}$ that seems inadequate for high demanding crops (Hartz et al. 1999; Lin et al. 2004; Mardanluo et al. 2018). Strawberry is among those plants that may havea higher potassium requirement for optimum fruiting and quality (Kaya et al. 2003; Khayyat et al. 2009; Ebrahimi et al. 2012), so inadequate potassium during fruit development can result in low quality fruits and early fruit decaying. It has been shown that increasing nutrient solution K from 235 to $300 \mathrm{mg} \mathrm{L}^{-1}$ significantly increased the strawberries yield and fruit quality traits including vitamin C and TSS (Ebrahimi et al. 2012). In pepper plants, increasing potassium in the nutrient solution to 400 and $500 \mathrm{mg} \mathrm{L}^{-1}$ significantly increased some growth and fruit quality traits (Mardanluo et al. 2018). In addition, higher $\mathrm{K}$ concentrations can significantly reduce the uptake and accumulation of toxic elements such as heavy metals, nitrates and sodium in plant edible tissues (Cerda et al. 2008; Ghazi and Al-Karaki 2008; Khayyat et al. 2009; Yildrim et al. 2009; Marschner 2011). Therefore, in the present study different concentrations of potassium of nutrient solution were applied to evaluate their effects on growth and fruit biochemical quality parameters of three genotypes of strawberry under hydroponic system.

\section{Material and Methods}

This study was conducted to evaluate the growth, yield and quality responses of three strawberry genotypes to various potassium concentrations of nutrient solution under greenhouse conditions. Different concentrations of potassium of nutrient solution including 235 (control), 350, 450 and $600 \mathrm{mg} \mathrm{L}^{-1}$ were applied to three strawberry genotypes of Camarosa, Selva and Parus (Mardanluo et al. 2018). The treatments were arranged in a randomized design with four replications. Each replicate was a pot with approximately four liters volume (filled with cocopeat and perlite mixture) containing two strawberries plants. The average record of two plants was used for each replication.

The pot medium was consisted of cocopeat: perlite in a 2:1 ratio, and the nutrient solution was prepared based on Hoagland formula with some modifications (Hoagland and Arnon 1950). Potassium sulfate was used for preparation of $\mathrm{K}$ concentration treatments. The initial $\mathrm{pH}$ of nutrient solution was adjusted to 5.8 using $\mathrm{H}_{2} \mathrm{SO}_{4}$. The pots were irrigated with nutrient solution three times per day for 20-30 min, and every ten days pots were washed with sufficient drinking tap water for prevention of salt accumulation in pots. The day/night temperature was adjusted on $25 / 18 \pm 3^{\circ} \mathrm{C}$, and the greenhouse humidity was in range of $60-70 \%$.

The experiment was run for five months and various plant growth traits were measured during experiment period or at harvest. Leaf SPAD value (The Soil and Plant Analysis Development) was measured using a portable SPAD meter (model 502 Plus, Illinois, USA). The average of 30 reading per pot was recorded as SPAD value of plants. Plant leaf area was measured using a leaf area meter (Model CI202, Germany) and single leaf area was presented in the results. At the end of experiment, shoot and root of plants were cut, and plant roots were precisely separated and washed from medium materials. Shoot and root fresh weights were determined using a digital balance. Plant shoot and root dry weights were determined and calculated after drying of shoots and roots at $65^{\circ} \mathrm{C}$ for $24 \mathrm{~h}$. The cumulative number of fruits per plant was recorded during experiment. The plant yield (g) was calculated from cumulative harvest of fruits during three months of fruiting period. The fruit length and fruit diameter were measured using a caliper (model Mitutoyo Japan).

Biochemical quality parameters of fruit juice were determined from fruits of final harvest. For preparation of fruit juice, fruits were squeezed manually and then centrifuged for 10 min for separation of the supernatant. Fruit juice $\mathrm{pH}$ was measured using a $\mathrm{pH}$ meter. Vitamin $\mathrm{C}$ (L-ascorbic acid) concentration of fruits was determined using the indophenols method (Aslani and Souri 2018). Briefly, $20 \mathrm{~g}$ of fresh fruit was crushed by hand in a mortal while receiving $20 \mathrm{~mL}$ of $6 \%$ metaphosphoric acid. The mixture was centrifuged at $9000 \mathrm{rpm}$ at $4^{\circ} \mathrm{C}$ for $10 \mathrm{~min}$, and thereafter $5 \mathrm{~mL}$ of the supernatant was diluted to $10 \mathrm{~mL}$ using 2\% metaphosphoric acid. Dichlorophenol indophenol was used for titration of final solution, and the amount of L-ascorbic acid was determined and calculated by dilutions and the amount of used reagent following determination of various concentrations of standard L-ascorbic acid in the procedure. Total soluble solids (TSS) of fruit juice were determined using a portable refrectometer (Erma-D, Japan). Titratable acidity of fruit juice was determined by titration of fruit juice against 0.1 $\mathrm{N} \mathrm{NaOH}$ solution. The potassium concentration of leaves and fruits were determined using the flame photometry method.

Data were analyzed using SPSS (version 16), and comparison of means was performed at 5\% confidence level of Duncan multiple range test. 
Ethical approval: The conducted research is not related to either human or animal use.

\section{Results}

The results showed that leaf SPAD values of three strawberry genotypes were not significantly influenced by K concentrations of nutrient solution (Table 1), however in Parus and Selva higher K levels resulted in slightly higher leaf SPAD value compared to control. Plant leaf area was significantly affected by K levels and in the three cultivars the significant maximum leaf area was observed in $350 \mathrm{mg} \mathrm{L}^{-1} \mathrm{~K}$ and the lowest leaf area was in $600 \mathrm{mg} \mathrm{L}^{-1}$ $\mathrm{K}$ of nutrient solution (Table 1). The maximum plant shoot fresh weight of Camarosa was in $350 \mathrm{mg} \mathrm{L}^{-1}$, and of Selva was in $400 \mathrm{mg} \mathrm{L}^{-1}$, and of Parus was in 350 and $400 \mathrm{mg}$ $\mathrm{L}^{-1} \mathrm{~K}$ of nutrient solution (Table 1). The significant lowest shoot fresh weight was in 235 (control) and $600 \mathrm{mg} \mathrm{L}^{-1} \mathrm{~K}$ of nutrient solution in all three cultivars.

Plant shoot dry weight of Camarosa was maximum at $350 \mathrm{mg} \mathrm{L}^{-1}$, while in Selva and Parus was maximum at 450 $\mathrm{mg} \mathrm{L}^{-1} \mathrm{~K}$ levels, which showed no significant difference to 350 and $600 \mathrm{mg} \mathrm{L}^{-1}$ treatments (Table 2). The lowest shoot dry weight in three cultivars was in control. Plant root fresh weight of Camarosa was not affected by $\mathrm{K}$ levels, but in Selva and Parus the maximum root fresh weight was in $350 \mathrm{mg} \mathrm{L}^{-1} \mathrm{~K}$ (Table 2). Root dry weight in Camarosa and Parus was not affected by $\mathrm{K}$ levels, while in Selva the maximum root dry weight was in $350 \mathrm{mg} \mathrm{L}^{-1}$ that showed significant difference to control and $600 \mathrm{mg} \mathrm{L}^{-1} \mathrm{~K}$.

Plant fruit fresh yield was not affected by $\mathrm{K}$ levels in Parus, but in Selva three higher K levels produced higher yield compared to control (Table 3); however, the maximum yield was obtained from $450 \mathrm{mg} \mathrm{L}^{-1} \mathrm{~K}$ level. In Camarosa $350 \mathrm{mg} \mathrm{L}^{-1} \mathrm{~K}$ produced the maximum yield that showed difference with control and $600 \mathrm{mg} \mathrm{L}^{-1} \mathrm{~K}$ levels (Table 3). Fruit number per plant was not affected by $\mathrm{K}$ levels in Camarosa, but in Selva and Parus, treatment with $350 \mathrm{mg} \mathrm{L}^{-1} \mathrm{~K}$ produced more fruits compared to control and $600 \mathrm{mg} \mathrm{L}^{-1} \mathrm{~K}$ treatments (Table 3). In Camarosa and Parus fruit length was highest in $350 \mathrm{mg} \mathrm{L}^{-1} \mathrm{~K}$ of nutrient solution, and there was no difference among other K levels (Table 3). Similarly, in Selva the maximum fruit length was in 350 $\mathrm{mg} \mathrm{L}^{-1} \mathrm{~K}$ that showed significant difference only to control plants, while there was no significant difference among high K levels.

In Parus cultivar fruit diameter was not affected by $\mathrm{K}$ levels of nutrient solution (Table 4). In Camarosa and Selva the significant maximum fruit diameter was in $350 \mathrm{mg} \mathrm{L}^{-1}$ $\mathrm{K}$; however, the lowest fruit diameter of Camarosa was in

Table 1. Leaf SPAD value, leaf area and shoot fresh weight of strawberries plant under different $K$ levels of nutrient solution.

\begin{tabular}{cccccccccc}
\hline \multicolumn{4}{c}{ Leaf SPAD value } & \multicolumn{3}{c}{ Leaf area $\left(\mathbf{c m}^{2}\right)$} & & \multicolumn{2}{c}{ Shoot FW (g) } \\
\hline $\begin{array}{c}\text { K Levels } \\
\left(\mathbf{m g ~ L}^{-1}\right)\end{array}$ & Camarosa & Selva & Parus & Camarosa & Selva & Parus & Camarosa & Selva & Parus \\
\hline 235 & $23 \pm 2.1 \mathrm{a}$ & $24 \pm 1.4 \mathrm{a}$ & $21 \pm 2.4 \mathrm{a}$ & $104 \pm 1.9 \mathrm{~b}$ & $102 \pm 4.2 \mathrm{ab}$ & $106 \pm 3.3 \mathrm{ab}$ & $51 \pm 3.9 \mathrm{~b}$ & $57 \pm 5.1 \mathrm{~b}$ & $49 \pm 5 \mathrm{~b}$ \\
350 & $23 \pm 1.6 \mathrm{a}$ & $26 \pm 2.5 \mathrm{a}$ & $23 \pm 1.3 \mathrm{a}$ & $110 \pm 4.2 \mathrm{a}$ & $109 \pm 4.6 \mathrm{a}$ & $113 \pm 8.5 \mathrm{a}$ & $59 \pm 5.9 \mathrm{a}$ & $62 \pm 7.8 \mathrm{ab}$ & $61 \pm 7 \mathrm{a}$ \\
450 & $22 \pm 2.2 \mathrm{a}$ & $25 \pm 2.1 \mathrm{a}$ & $23 \pm 2.8 \mathrm{a}$ & $102 \pm 5.1 \mathrm{~b}$ & $105 \pm 7.5 \mathrm{ab}$ & $105 \pm 6.8 \mathrm{ab}$ & $52 \pm 4.8 \mathrm{ab}$ & $66 \pm 9.1 \mathrm{a}$ & $58 \pm 5.1 \mathrm{a}$ \\
600 & $21 \pm 2.5 \mathrm{a}$ & $24 \pm 3.7 \mathrm{a}$ & $22 \pm 2.7 \mathrm{a}$ & $100 \pm 7.9 \mathrm{~b}$ & $98 \pm 2.8 \mathrm{~b}$ & $98 \pm 4.6 \mathrm{~b}$ & $50 \pm 5.5 \mathrm{~b}$ & $57 \pm 6.5 \mathrm{~b}$ & $56 \pm 8.2 \mathrm{ab}$ \\
\hline
\end{tabular}

- FW represents fresh weight.

- Comparison of means was performed at $5 \%$ level of Duncan's multiple range test.

- Plants were grown for five months with treatments.

Table 2. Shoot dry weight, root fresh weight and root dry weight of strawberries plant under different K levels of nutrient solution.

\begin{tabular}{cccccccccc}
\hline & \multicolumn{3}{c}{ Shoot DW (g) } & \multicolumn{3}{c}{ Root FW (g) } & & \multicolumn{2}{c}{ Root DW (g) } \\
\hline $\begin{array}{c}\text { K Levels } \\
\left(\mathbf{m g ~ L}^{-1}\right)\end{array}$ & Camarosa & Selva & Parus & Camarosa & Selva & Parus & Camarosa & Selva & Parus \\
\hline 235 & $9.5 \pm 0.7 \mathrm{~b}$ & $10.4 \pm 0.6 \mathrm{~b}$ & $9.2 \pm 0.4 \mathrm{~b}$ & $15.9 \pm 2 \mathrm{a}$ & $16.1 \pm 1.4 \mathrm{ab}$ & $15.7 \pm 1.6 \mathrm{ab}$ & $2.9 \pm 0.3 \mathrm{~b}$ & $3.1 \pm 0.3 \mathrm{~b}$ & $3.1 \pm 0.2 \mathrm{a}$ \\
350 & $10.7 \pm 1.6 \mathrm{a}$ & $11.7 \pm 1.3 \mathrm{a}$ & $11.5 \pm 2.3 \mathrm{a}$ & $16.2 \pm 1.9 \mathrm{a}$ & $18.7 \pm 2.5 \mathrm{a}$ & $16.5 \pm 1.6 \mathrm{a}$ & $3.1 \pm 0.1 \mathrm{a}$ & $3.6 \pm 0.2 \mathrm{a}$ & $3.1 \pm 0.1 \mathrm{a}$ \\
450 & $9.6 \pm 0.5 \mathrm{~b}$ & $12.3 \pm 1 \mathrm{a}$ & $11.8 \pm 1.7 \mathrm{a}$ & $16.1 \pm 1.8 \mathrm{a}$ & $15.4 \pm 1.2 \mathrm{~b}$ & $15.2 \pm 2.8 \mathrm{~b}$ & $3 \pm 0.4 \mathrm{a}$ & $3.4 \pm 0.2 \mathrm{ab}$ & $3 \pm 0.3 \mathrm{a}$ \\
600 & $10.4 \pm 1.0 \mathrm{ab}$ & $11.9 \pm 1.3 \mathrm{a}$ & $11.5 \pm 1.9 \mathrm{a}$ & $16.2 \pm 1.4 \mathrm{a}$ & $15 \pm 1.8 \mathrm{~b}$ & $13.8 \pm 2.4 \mathrm{c}$ & $3.1 \pm 0.2 \mathrm{a}$ & $3.2 \pm 0.4 \mathrm{~b}$ & $3.1 \pm 0.4 \mathrm{a}$ \\
\hline
\end{tabular}

- FW and DW represent the dry weight and fresh weight, respectively.

- Comparison of means was performed at $5 \%$ level of Duncan's multiple range test.

- Plants were grown for five months with treatments. 
Table 3. Plant fruit yield, fruit number and fruit length of strawberry plants under different $\mathrm{K}$ levels of nutrient solution.

\begin{tabular}{cccccccccc}
\hline & \multicolumn{4}{c}{ Fruit fresh yield (g plant $\left.{ }^{-1}\right)$} & \multicolumn{3}{c}{ Fruit No per plant } & & \multicolumn{3}{c}{ Fruit length (cm) } \\
\hline $\begin{array}{c}\text { K Levels } \\
\left(\mathrm{mg} \mathrm{L}^{-1}\right)\end{array}$ & Camarosa & Selva & Parus & Camarosa & Selva & Parus & Camarosa & Selva & Parus \\
\hline 235 & $167 \pm 18 \mathrm{~b}$ & $261 \pm 17 \mathrm{c}$ & $165 \pm 20 \mathrm{a}$ & $14.7 \pm 2.2 \mathrm{a}$ & $24.8 \pm 1.7 \mathrm{~b}$ & $14.5 \pm 2.1 \mathrm{~b}$ & $3.3 \pm 0.23 \mathrm{~b}$ & $3.1 \pm 0.14 \mathrm{~b}$ & $3.1 \pm 0.22 \mathrm{~b}$ \\
350 & $194 \pm 37 \mathrm{a}$ & $323 \pm 36 \mathrm{ab}$ & $170 \pm 14 \mathrm{a}$ & $15.3 \pm 3.2 \mathrm{a}$ & $290 \pm 2.6 \mathrm{a}$ & $16.8 \pm 3.1 \mathrm{a}$ & $3.7 \pm 0.36 \mathrm{a}$ & $3.4 \pm 0.24 \mathrm{a}$ & $3.7 \pm 0.31 \mathrm{a}$ \\
450 & $175 \pm 10 \mathrm{ab}$ & $347 \pm 24 \mathrm{a}$ & $174 \pm 7 \mathrm{a}$ & $15 \pm 2.4 \mathrm{a}$ & $26 \pm 2.2 \mathrm{ab}$ & $15.7 \pm 2 \mathrm{ab}$ & $3.1 \pm 0.12 \mathrm{~b}$ & $3.3 \pm 0.26 \mathrm{ab}$ & $3.1 \pm 0.20 \mathrm{~b}$ \\
600 & $164 \pm 13 \mathrm{~b}$ & $305 \pm 18 \mathrm{~b}$ & $163 \pm 8 \mathrm{a}$ & $14.8 \pm 2.2 \mathrm{a}$ & $25.2 \pm 2.8 \mathrm{~b}$ & $14.7 \pm 2.5 \mathrm{~b}$ & $3.1 \pm 0.21 \mathrm{~b}$ & $3.3 \pm 0.15 \mathrm{ab}$ & $3.0 \pm 0.21 \mathrm{~b}$ \\
\hline
\end{tabular}

- Comparison of means was performed at $5 \%$ level of Duncan's multiple range test.

- Plants were grown for five months with treatments.

Table 4. Fruit diameter, vitamin $\mathrm{C}$ and titratable acidity content of strawberry cultivars under different $\mathrm{K}$ levels of nutrient solution.

\begin{tabular}{cccccccccc}
\hline & \multicolumn{3}{c}{ Fruit diameter $(\mathbf{c m})$} & \multicolumn{2}{c}{ Vitamin C (mg 100 g FW $\left.\mathbf{~}^{-1}\right)$} & \multicolumn{3}{c}{ Titratable acdity (\%) } \\
\hline $\begin{array}{c}\text { K Levels } \\
\left(\mathrm{mg} \mathrm{L}^{-1}\right)\end{array}$ & Camarosa & Selva & Parus & Camarosa & Selva & Parus & Camarosa & Selva & Parus \\
\hline 235 & $2.8 \pm 0.07 \mathrm{~b}$ & $2.8 \pm 0.04 \mathrm{ab}$ & $2.9 \pm 0.07 \mathrm{a}$ & $28.7 \pm 2.6 \mathrm{ab}$ & $28.1 \pm 3.3 \mathrm{ab}$ & $24.1 \pm 2.5 \mathrm{~b}$ & $1.14 \pm 0.03 \mathrm{a}$ & $1.18 \pm 0.05 \mathrm{a}$ & $0.92 \pm 0.12 \mathrm{~b}$ \\
350 & $3.0 \pm 0.06 \mathrm{a}$ & $2.9 \pm 0.05 \mathrm{a}$ & $2.8 \pm 0.08 \mathrm{a}$ & $31.1 \pm 3.5 \mathrm{a}$ & $33.1 \pm 4.2 \mathrm{a}$ & $22.9 \pm 3.4 \mathrm{bc}$ & $1.16 \pm 0.02 \mathrm{a}$ & $1.17 \pm 0.04 \mathrm{a}$ & $0.94 \pm 0.10 \mathrm{~b}$ \\
450 & $2.9 \pm 0.07 \mathrm{ab}$ & $2.8 \pm 0.09 \mathrm{ab}$ & $2.8 \pm 0.09 \mathrm{a}$ & $27.9 \pm 2.1 \mathrm{ab}$ & $28.3 \pm 3.1 \mathrm{ab}$ & $30 \pm 2.1 \mathrm{a}$ & $1.17 \pm 0.02 \mathrm{a}$ & $1.2 \pm 0.04 \mathrm{a}$ & $1.13 \pm 0.03 \mathrm{a}$ \\
600 & $2.9 \pm 0.06 \mathrm{ab}$ & $2.7 \pm 0.15 \mathrm{~b}$ & $2.7 \pm 0.14 \mathrm{a}$ & $26.1 \pm 1.6 \mathrm{~b}$ & $26.7 \pm 3.8 \mathrm{~b}$ & $20.3 \pm 3 \mathrm{c}$ & $1.15 \pm 0.03 \mathrm{a}$ & $1.18 \pm 0.03 \mathrm{a}$ & $1.10 \pm 0.02 \mathrm{a}$ \\
\hline
\end{tabular}

-FW represents fresh weight.

- Comparison of means was performed at $5 \%$ level of Duncan's multiple range test.

- Plants were grown for five months with treatments.

control, and of Selva was in $600 \mathrm{mg} \mathrm{L}^{-1} \mathrm{~K}$. Determination of fruit vitamin $\mathrm{C}$ content in three strawberry cultivars showed that fruit vitamin $\mathrm{C}$ was significantly influenced by K levels of nutrient solution (Table 4). In Camarosa and Selva, the changes of vitamin $\mathrm{C}$ were almost similar, in which the maximum fruit vitamin $\mathrm{C}$ was in $350 \mathrm{mg} \mathrm{L}^{-1} \mathrm{~K}$ and the significant lowest was in $600 \mathrm{mg} \mathrm{L}^{-1} \mathrm{~K}$. In Parus cultivar, the maximum fruit vitamin $\mathrm{C}$ was in $450 \mathrm{mg} \mathrm{L}^{-1}$ $\mathrm{K}$ and the lowest value was in $600 \mathrm{mg} \mathrm{L}^{-1} \mathrm{~K}$ of nutrient solution (Table 4). Fruit titratable acidity was not affected by $\mathrm{K}$ levels in Camarosa and Selva cultivars, while in Parus the two maximum $\mathrm{K}$ levels ( 450 and $600 \mathrm{mg} \mathrm{L}^{-1} \mathrm{~K}$ ) resulted in significantly higher titratable acidity than other two concentrations (Table 4).

Fruit TSS was not affected by K levels in Parus cultivar (Table 5). In Camarosa and Selva fruit TSS was significantly higher in 350 and $450 \mathrm{mg} \mathrm{L}^{-1} \mathrm{~K}$ compared to control (Table 5). Fruit juice $\mathrm{pH}$ was not affected by $\mathrm{K}$ levels in Camarosa and Selva cultivars (Table 5). Fruit juice $\mathrm{pH}$ in Parus was significantly higher in 350 and $450 \mathrm{mg} \mathrm{L}^{-1} \mathrm{~K}$ treatments compared to control and $600 \mathrm{mg} \mathrm{L}^{-1} \mathrm{~K}$ treatment (Table 5).

Determination of leaf potassium concentration (Table 6) showed that the maximum value in three cultivars was in maximum $\mathrm{K}$ level of nutrient solution $\left(600 \mathrm{mg} \mathrm{L}^{-1} \mathrm{~K}\right)$ that in Selva and Parus showed no significant difference to
$450 \mathrm{mg} \mathrm{L}^{-1} \mathrm{~K}$ treatment. In the three genotypes the lowest leaf $\mathrm{K}$ concentration was observed in control plants. Fruit K concentration (Table 6) was not followed leaf $\mathrm{N}$ concentration in Camarosa and Selva cultivars. However, in the three cultivars fruit $\mathrm{K}$ concentration showed no significant difference among 350, 450 and $600 \mathrm{mg} \mathrm{L}^{-1} \mathrm{~K}$ levels, while the maximum fruit $\mathrm{K}$ in Camarosa was in 359 $\mathrm{mg} \mathrm{L}^{-1} \mathrm{~K}$, in Selva was in $450 \mathrm{mg} \mathrm{L}^{-1} \mathrm{~K}$ and in Parus was in $600 \mathrm{mg} \mathrm{L}^{-1} \mathrm{~K}$ of nutrient solution. In the three cultivars the lowest fruit $\mathrm{K}$ concentration was in control treatment (Table 6).

\section{Discussion}

In the present study it was shown that the three strawberry genotypes had general positive response to higher potassium levels of nutrient solution. However, various growth, yield and quality traits had different responses to $\mathrm{K}$ levels of nutrient solution in the three genotypes. Application of $350 \mathrm{mg} \mathrm{L}^{-1}$ and for some traits $450 \mathrm{mg} \mathrm{L}^{-1}$ potassium instead of routine Hoagland $\mathrm{K}$ concentration of $235 \mathrm{mg} \mathrm{L}^{-1}$ (as control) significantly improved vegetative, yield and quality parameters of the three strawberry genotypes. Increase in plant growth characteristics and quality parameters via application of potassium have 
Table 5. Fruit total soluble solids (TSS) and fruit pH of three strawberry cultivars under different $\mathrm{K}$ levels of nutrient solution.

\begin{tabular}{ccccccc}
\hline & \multicolumn{3}{c}{ Fruit TSS (\%) } & & & \multicolumn{2}{c}{ Fruit juice pH } \\
\hline $\begin{array}{c}\text { K Levels } \\
\left(\mathrm{mg} \mathrm{L}^{-1}\right)\end{array}$ & Camarosa & Selva & Parus & Camarosa & Selva & Parus \\
\hline 235 & $5.3 \pm 0.04 \mathrm{~b}$ & $5.1 \pm 0.07 \mathrm{~b}$ & $5.2 \pm 0.08 \mathrm{a}$ & $1.35 \pm 0.06 \mathrm{a}$ & $1.48 \pm 0.04 \mathrm{a}$ & $1.42 \pm 0.04 \mathrm{~b}$ \\
350 & $5.5 \pm 0.08 \mathrm{a}$ & $5.3 \pm 0.11 \mathrm{a}$ & $5.2 \pm 0.09 \mathrm{a}$ & $1.37 \pm 0.05 \mathrm{a}$ & $1.54 \pm 0.06 \mathrm{a}$ & $1.54 \pm 0.07 \mathrm{a}$ \\
450 & $5.5 \pm 0.04 \mathrm{a}$ & $5.3 \pm 0.07 \mathrm{a}$ & $5.2 \pm 0.05 \mathrm{a}$ & $1.39 \pm 0.04 \mathrm{a}$ & $1.53 \pm 0.04 \mathrm{a}$ & $1.58 \pm 0.07 \mathrm{a}$ \\
600 & $5.4 \pm 0.06 \mathrm{ab}$ & $5.1 \pm 0.10 \mathrm{~b}$ & $5.2 \pm 0.07 \mathrm{a}$ & $1.34 \pm 0.03 \mathrm{a}$ & $1.46 \pm 0.04 \mathrm{a}$ & $1.44 \pm 0.08 \mathrm{~b}$ \\
\hline
\end{tabular}

- TSS represents the Total Soluble Solids.

- Comparison of means was performed at $5 \%$ level of Duncan's multiple range test.

- Plants were grown for five months with treatments.

Table 6. Potassium concentration of leaf and fruits of three strawberry genotypes under different $\mathrm{K}$ levels of nutrient solution.

\begin{tabular}{cccccccc}
\hline & \multicolumn{3}{c}{ Leaf K con. (\% DW) } & \multicolumn{3}{c}{ Fruit K con. (mg kg FW-1) } \\
\hline $\begin{array}{c}\text { K Levels } \\
\left(\mathrm{mg} \mathrm{L}^{-1}\right)\end{array}$ & Camarosa & Selva & Parus & Camarosa & Selva & Parus \\
\hline 235 & $1.5 \pm 0.12 \mathrm{c}$ & $1.6 \pm 0.17 \mathrm{~b}$ & $1.7 \pm 0.13 \mathrm{c}$ & $1557 \pm 125 \mathrm{~b}$ & $1632 \pm 171 \mathrm{~b}$ & $1890 \pm 118 \mathrm{~b}$ \\
350 & $1.8 \pm 0.20 \mathrm{~b}$ & $1.8 \pm 0.14 \mathrm{ab}$ & $2.0 \pm 0.18 \mathrm{bc}$ & $1720 \pm 103 \mathrm{a}$ & $1981 \pm 192 \mathrm{ab}$ & $2011 \pm 122 \mathrm{a}$ & \\
450 & $1.8 \pm 0.22 \mathrm{~b}$ & $2.0 \pm 0.15 \mathrm{a}$ & $2.2 \pm 0.25 \mathrm{ab}$ & $1629 \pm 83 \mathrm{ab}$ & $2097 \pm 128 \mathrm{a}$ & $2040 \pm 67 \mathrm{a}$ & \\
600 & $2.3 \pm 0.31 \mathrm{a}$ & $2.0 \pm 0.18 \mathrm{a}$ & $2.5 \pm 0.24 \mathrm{a}$ & $1621 \pm 77 \mathrm{ab}$ & $1938 \pm 109 \mathrm{ab}$ & $2102 \pm 70 \mathrm{a}$ \\
\hline
\end{tabular}

- FW and DW represent the dry weight and fresh weight, respectively.

- Comparison of means was performed at $5 \%$ level of Duncan's multiple range test.

- Plants were grown for five months with treatments.

been also reported in other studies (Kaya et al. 2003; Kaye et al. 2006; Fageria et al. 2007; Cerda et al. 2008; Ghazi and Al-Karaki 2008; Mardanlu et al. 2014; Mardanlu et al. 2018). However, in Galia melon, fruit number and fruit firmness but not fruit yield was improved by 400 and 600 $\mathrm{mg} \mathrm{L}^{-1}$ than $200 \mathrm{mg} \mathrm{L}^{-1}$ potassium concentration (Demiral and Köseoglu 2004). In strawberry, it was shown that increasing the concentration of potassium to $300 \mathrm{mg} \mathrm{L}^{-1}$ in nutrient solution increased vitamin C content, TSS, fruit number, fruit weight, plant yield, root biomass and root length (Ebrahimi et al. 2012).

Potassium is key element involved in photosynthesis, sugar biosynthesis and translocation, stomata behavior and plant water relations, osmotic adjustment, anioncation equilibrium, cell and plant growth, root growth, increasing nutrients particularly nitrogen use efficiency, with extra roles in plant tolerance to biotic and abiotic stress, and many other functions (Kaya et al. 2003; Walter and Difonzo 2007; Marschner 2011; Mardanlu et al. 2014). Due to these fundamental roles, there may be always positive response of plants to applied potassium particularly to the root medium. Foliar application of potassium on olive trees (Zivdar et al. 2017), tomato plants (Hartz et al. 1999), melons (Lester et al. 2006) and strawberry (Yildrim et al. 2009) has increased the plant vegetative growth, phytochemicals, fruit quality and marketable yield.

In our study, quality traits of strawberry fruits were also improved by higher $\mathrm{K}$ concentrations of 350 and for some other traits by $450 \mathrm{mg} \mathrm{L}^{-1}$. Different potassium concentrations of nutrient solution on Cucumis melo cv. reticulates showed that increasing $\mathrm{K}$ levels resulted in higher levels of sugars, soluble solids, glutamic acid, aspartic acid, alanine, and volatile acetate compounds in fruit tissues, despite there was no significant effect of $\mathrm{K}$ levels on fruit size and its appearance (Lin et al. 2004). Application of $\mathrm{K}$ in soil or on foliages during fruit growth in melons can improve fruit quality, sugar content, ascorbic acid and $ß$-carotene (Laster et al. 2006).

Potassium is a key mineral in plant photoassimilate production, their translocation and storage in plant tissues and higher $\mathrm{K}$ levels, depending on plant species and environmental conditions, may improve plant photosynthesis and photoassimilate production (El-Bassiony 2006; Marschner 2011; Zivdar et al. 2016). So it can be deducted that in the present study potassium with increasing higher chlorophyll efficiency and photosynthesis rate has affected many enzymatic 
reactions toward better biochemical and quality traits (Rubio et al. 2010; Marschner 2011, Mardanluo et al. 2018).

Increase in biochemical quality traits of strawberry by higher $\mathrm{K}$ levels indicates higher potassium requirements of plants particularly during fruiting stage. Similar results were reported on chili pepper and bell pepper using higher $\mathrm{K}$ levels, in which $400 \mathrm{mg} \mathrm{L}^{-1} \mathrm{~K}$ in nutrient solution improved many quality parameters including vitamin C and TSS (Mardanlu et al. 2014; Mardanluo et al. 2018). The highest yield and fruit quality parameters including fruit length/diameter ratio, fruit dry matter percentage, fruit vitamin C, total soluble solids, and titratable acidity in chili pepper and bell pepper were obtained under application of 300 and $400 \mathrm{mg} \mathrm{L}^{-1} \mathrm{~K}$ in nutrient solution, respectively. In either cultivar there was increase in leaf $\mathrm{K}$, nitrogen, and zinc concentrations, while in bell pepper calcium was reduced by higher $\mathrm{K}$ levels in the nutrient solution (Mardanluo et al. 2018). Foliar application of potassium on olive trees significantly improved fruit biochemical and oil characteristics (Zivdar et al. 2017). Application of higher $\mathrm{K}$ levels of 400 and $600 \mathrm{mg} \mathrm{L}^{-1}$ increased fruit biochemical characteristics such as soluble solids in Galia melons, whereas the leaf concentration of $\mathrm{N}, \mathrm{P}, \mathrm{Ca}, \mathrm{Mg}$ and $\mathrm{Zn}$ were not affected by $\mathrm{K}$ levels of nutrient solution, but leaf $\mathrm{K}$ content was higher than the control by higher $\mathrm{K}$ rates and $\mathrm{Fe}$ and $\mathrm{Mn}$ was reduced by application of 600 $\mathrm{mg} \mathrm{L}^{-1} \mathrm{~K}$ in nutrient solution (Demiral and Köseoglu 2004).

Higher potassium concentration in plant tissues is always a quality factor and may have various beneficial effects including; amelioration of the negative effects of salinity on strawberry plant growth and fruit yield (Kaya et al. 2003; Rubio et al. 2010), higher chlorophyll efficiency, more photosynthesis, better translocation and storage of photoassimilate, and increased biochemical quality parameters (Hartz et al. 1999; Kaye et al. 2006; Marschner 2011; Ebrahimi et al. 2012). Plant genotypes that have better tolerance to salinity or drought generally have improved $\mathrm{K}$ uptake and concentrations (Ghazi and Al-Karaki 2008; Marschner 2011). In cucumber and pepper under $\mathrm{NaCl}$ salinity, supplementary $\mathrm{K}$ restored dry matter and chlorophyll concentrations to levels similar to the control plants (Kaya et al. 2001). In tomato, genotypes with higher K uptake generally show increased water use efficiency and salinity tolerance (Ghazi, and Al-Karaki 2008). Higher $K$ levels may also restrict disease and damage by pests (San Bautista et al. 2009), as it has been shown that aphid population densities are higher on potassium-deficient than on healthy soybeans (Walter and Difonzo 2007).

In the present study, Selva genotype responded better to increasing $\mathrm{K}$ levels of nutrient solution than other two genotypes of Camarosa and Parus. Among three cultivars, Selva had the maximum number of fruits per plant and yield production. There was no effect of $\mathrm{K}$ levels on fruit yield (in Parus), fruit number (in Camarosa), root dry weight (in Camarosa and Parus), fruit titratable acidity (in Camarosa and Selva), and fruit TSS (in Parus). However, different $\mathrm{K}$ levels of nutrient solution showed significant effects on these traits in the case of other genotype(s). Genetic differences among various plant species and cultivars are well known regarding their ability to absorb or translocate the nutrient elements (Marschner 2011). Such differences also exist particularly regarding $\mathrm{K}$ uptake and translocation (Fageria et al. 2007). Maize cultivars respond differently to low and high $\mathrm{K}$ levels of nutrient solution (Cerda et al. 2008). In low K, the growth of maize cultivars showed no difference while at higher K "Spirit" cultivar produced 1.5 times more biomass than "Jubileo" cultivar (Cerda et al. 2008). However, in Galia melons different $\mathrm{K}$ concentrations of nutrient solution had no effect on yield, but it improved fruit quality by applying as much as $600 \mathrm{mg} \mathrm{L}^{-1}$ additional $\mathrm{K}$ to the plants without a reduction in yield (Demiral and Köseoglu 2004). Similar results were obtained on growth and fruit quality of chili pepper and bell pepper under hydroponic system (Mardanlu et al. 2014; Mardanluo et al. 2018).

\section{Conclusion}

The results indicate that plant overall growth and fruit quality of three strawberry genotypes had positive response to $350 \mathrm{mg} \mathrm{L}^{-1}$, while application of $600 \mathrm{mg} \mathrm{L}^{-1}$ potassium reduced most of plant growth and quality traits than control (235 mg L-1). Among genotypes Selva had better response to higher concentration of $\mathrm{K}$ than two other genotypes of Camarosa and Parus. Therefore, increasing K concentration of nutrient solution to $350 \mathrm{mg}$ $\mathrm{L}^{-1}$ can benefits plant growth and improve several fruit quality-related traits in strawberry.

Conflict of interest: Authors declare no conflict of interest.

\section{References}

Aslani, M., Souri M.K., Growth and quality of green bean (Phaseolus vulgaris L.) under foliar application of organic-chelate fertilizers. Open Agri., 2018, 3(1), 146-154

Cerda A., Pardines J., Botella M.A., Martinez V., Effect of potassium on growth, water relations, and the inorganic and organic solute contents for two maize cultivars grown under saline conditions. J. Plant Nutrition, 2008, 18(4), 839-851 
Demiral M., Koseoglu A., Effect of potassium on yield, fruit quality, and chemical composition of greenhouse-grown galia melon. J. Plant Nutrition, 2005, 28, 93-100

El-Bassiony A.M., Effect of potassium fertilization on growth, yield and quality of onion plants. J. Applied Sciences Research, 2006, 2(10), 780-785

Ebrahimi R., Souri M.K., Ebrahimi F., Ahmadizadeh M., Growth and yield of strawberries under different potassium concentrations of hydroponic system in three substrates. World Appl. Sci. J, 2012, 16(10), 1380-1386

Fageria N.K., Barbosa Filho M.P., Da Costa J.G.C., Potassium use efficiency in common bean genotypes. J. Plant Nutrition, 2007, 24(12), 1937-1945

Ghazi N., Al-Karaki, Growth, water use efficiency and sodium and potassium acquisition by tomato cultivars grown under salt stress. J. Plant Nutrition, 2008, 23(1), 1-8

Hartz T.K., Miyao G., Mullen R.J., Cahn M.D., Valenyat Cia J., Brittan K.L., Potassium requirements for maximum yield and fruit quality of processing tomato. J. Am. Soc. Hort. Sci., 1999, 124, 199-204

Hoagland D.R., Arnon D.I., The water-culture method for growing plants without soil. California Agricultural Experiment Station Circular, 1950, 347, 1-32

Human C., Kotze A., Effect of nitrogen and potassium fertilization on strawberries in an annual hill culture system: 3 . Leaf nutrient levels. Commun. Soil Sci. Plant Anal., 1990, 21, 795-810

Kaya C., Ak B.E., Higgs D., Response of salt-stressed strawberry plants to supplementary calcium nitrate and/or potassium nitrate. J. Plant Nutrition, 2003, 26(3), 543-560

Kaya C., Kirnak H., Higgs D., Effects of supplementary potassium and phosphorus on physiological development and mineral nutrition of cucumber and pepper cultivars grown at high salinity ( $\mathrm{NaCl})$. J. Plant Nutrition, 2001, 24(9), 1457-1471

Khayyat M., Tafazoli E., Rajaee S., Vazifeshenas M., Mahmoodabadi M.R., Sajjadinia A., Effects of $\mathrm{NaCl}$ and supplementary potassium on gas exchange, ionic content, and growth of salt-stressed strawberry plants. J. Plant Nutrition, 2009, 32(6), 907-918
Lester G.E., Jifon J.L., Makus D.J., Supplemental foliar potassium applications with or without a surfactant can enhance netted muskmelon quality. HortScience, 2006, 41(3), 741-744

Lin D., Huang D., Wang S., Effects of potassium levels on fruit quality of muskmelon in soilless medium culture. Scientia Horticulturae, 2004, 102, 53-60

Mardanlu S., Souri M.K., Dehnavard S., Evaluation of quantity and quality characteristics of chili pepper fruit under different potassium levels of nutrient solution in hydroponic culture. Iranian J. of Soil Research, 2014, 28, 397-406

Mardanluo S., Souri M.K., Ahmadi M., Plant growth and fruit quality of two pepper cultivars under different potassium levels of nutrient solutions. Journal of Plant Nutrition, 2018, 41(12), 1604-1614

Marschner H., Marschner's mineral nutrition of higher plants. Third Edition, Academic Press, London, 2011

Rubio J.S., Garcia-Sanchez F., Flores P., Navarro J.M., Martinez V., Yield and fruit quality of sweet pepper in response to fertilization with $\mathrm{Ca}^{2+}$ and $\mathrm{K}^{+}$. Spanish J. Agricultural Research, 2010, 8(1), 170-177

San Bautista A., Loez-Galarza S., Martínez A., Pascual B., Maroto J.V., Influence of cation proportions of the nutrient solution on tipburn incidence in strawberry plants. J. Plant Nutrition, 2009, 32, 1527-1539

Souri M.K., Aminochelate fertilizers: the new approach to the old problem; a review, Open Agri., 2016, 1, 118-123

Walter A.J., Difonzo D.C., Soil potassium deficiency affects soybean phloem nitrogen and soybean aphid populations. Environ. Entomology, 2007, 36, 26-33

Yildrim E., Karlidag H., Turan M., Mitigation of salt stress in strawberry by foliar K, Ca and Mg nutrient supply. Plant Soil Environ., 2009, 55, 213-221

Zivdar S.H., Arzani K., Souri M.K., Moallemi N., Seyyednejad S.M., Physiological and biochemical response of olive (Olea europaea L.) cultivars to foliar potassium application. J. Agr. Sci. Tech., 2016, 18, 1897-1908 